\title{
REFERENCES
}

Diachenko, 1981 - Diachenko M. Y., Kandybovych L. A. Psykholohyia vysshei shkoly: uchenyk. Mynsk : Yzdatelstvo BHU ym. V. Y. Lenyna, 1981. $383 \mathrm{~s}$.

Zeer, 2006 - Zeer E. F. Psykholohyia professyi : ucheb.posob. dlia studentov vuzov. Moskva : Akademycheskyi Proekt; Fond «Myr», 2006. $336 \mathrm{~s}$.

Povarenkov, 2002 - Povarenkov Yu. P. Psykholohycheskoe soderzhanye professyonalnoho stanovlenyia cheloveka. Moskva : Yzd-vo URAO, 2002. $160 \mathrm{~s}$.

Subbotyna, 2011 - Subbotyna L. Yu. Formyrovanye professyonalnoi hotovnosty studentov k samostoiatelnoi deiatelnosty. Yaroslavskyi pedahohycheskyi vestnyk. 2011. № 4. T. II. S. 295298.

Shypylova, 2007 - Shypylova E. V. Formyrovanye psykholohycheskoi hotovnosty studentovpsykholohov k professyonalnoi deiatelnosty : avtoref. dys. na soysk. nauch. stepeny kand. psykhol. nauk : spets. 19.00.07 «Pedahohycheskaia psykholohyia». Moskva, 2007. 20 s.

\author{
Таїсія Ткачук, \\ доктор психологічних наук, \\ професор, завідувач кафедри \\ практичної психологї \\ ДВНЗ «Переяслав-Хмельницький \\ державний педагогічний \\ університет імені Григорія \\ Сковороди» \\ Анастасія Іщенко, \\ студентка педагогічного \\ факультету ДВНЗ «Переяслав- \\ Хмельницький державний \\ педагогічний університет імені \\ Григорія Сковороди»
}

E-mail: taisiya07@ukr.net

ORCID 0000-0002-2721-6392

\author{
Taisiia Tkachuk, \\ Doctor of Psychology, \\ Professor, Head of the Applied \\ Psychology Department \\ of the SHEI «Pereiaslav-Khmelnytskyi \\ Hryhorii Skovoroda \\ State Pedagogical University»
}

E-mail: nastyaishenko@ukr.net

ORCID 0000-0001-6169-8834

\section{ПСИХОЛОГІЧНІ ОСОБЛИВОСТІ ВЗАЕМОДІЇ ПОДРУЖЖЯ В КОНФЛІКТНИХ СИТУАЦІЯХ}

У статті обтрунтовано актуальність дослідження подружніх конфліктів як деструктивних чинників, щзо призводять до значного погіршення взаємин у сім'ях та їхнього розпаду. Проаналізовано особливості причин сімейних конфліктів, серед яких обмеження свободи активності, самовираження членів сім'ї, ненормативна поведінка одного або декількох членів сім'і, наявність протилежних інтересів, прагнень, обмеженість можливостей для задоволення потреби одного з членів сім'ї (з його точки зору); авторитарний, жорсткий тип сімейних взаємостосунків, наявність матеріальних проблем, авторитарне втручання родичів у подружні стосунки, сексуальна дисгармонія партнерів у шлюбі тощзо. Представлено результати власного емпіричного вивчення ефективності впровадження корекційної програми, спрямованої на формування навичок конструктивного розв'язання конфліктних ситуацій у сім'ї. Після 


\section{Psychology}

впровадження корекиійних заходів виявлено зменшення показників конфліктності за батьківсько-виховною шкалою, яка діагностує задоволення індивідуальних потреб у батьківстві й материнстві та самореалізачї особистості в дітях. Наголошено, щцо після формувального експерименту збільшився відсоток партнерів, задоволених способом існування та розвитком особистості іншого партнера як суб'єкта суспільного життя; покрашилися результати досліджуваних за інтимно-сексуальною та шкалою особистісної ідентифікації, втім меншою мірою. Зроблено висновки, що корекційні впливи сприяли формуванню навичок безконфліктного розв'язання проблемних ситуацій у сім' $і$, свідченням чому стали покращення комунікативних навичок спілкування партнерів, врахування інтересів та потреб один одного, розвиток доброзичливості та гармонізація взаємостосунків у родині.

Ключові слова: сім'я, молоде подружжя, цінності, конфлікт, конфліктна ситуація, причини конфліктів, рольові очікування, рольові домагання.

The article deals with the concept of marital conflict. The family is considered as a social institution. Identified marital conflicts that occur more often, as well as the most important causes of family conflicts. The views of scientists involved in the study of this problem are analyzed. The analysis of scientific and psychological literature on the problem under investigation is covered. A corrected program «Resolution of marital conflicts and harmonization of family relations» was formed and tested, the task of which is to acquaint the couple with the concept of «conflict»; ability to manage conflict situations; teach to appreciate your partner and help each other; develop forms and skills of personal communication, ways of understanding. The results of their own empirical study of role expectations and claims in the married couple are presented. Graphically in percentages, results are shown using the method "Role expectations and harassment in marriage» (ROD) AN Volkova Comparatively significant difference between the indicators of the observational and experimental research, after the introduction of correctional program. The effectiveness of the correction program is analyzed. It is proved that the prevention of family conflicts depends, first of all, on the marriage. The ways of resolving conflicts are determined. It is noted that after the introduction of corrective measures, a reduction in the indicators of conflict on the parental educational scale, which diagnoses the satisfaction of individual needs in parenthood and parenthood and self-realization of the individual in children, is revealed. It is also noted that after the molding experiment, the percentage of partners, satisfied with the way of existence and development of the personality of another partner as a subject of public life, increased.

Keywords: family, young marriage, values, conflict, conflict situation, compromise, adaptation, rivalry, avoidance, cooperation, respect.

Постановка проблеми. Сім'я - одна із найвеличніших цінностей, що створені людством за період свого існування. Жодна нація, жодне історичне суспільство не обходиться без сім’ї. Це соціальний інститут, який не лише забезпечує стабільність суспільства, але й еволюціонує разом 3 ним та адаптується до новацій і змін. 3 іншого боку, сім'я виступає як місце первинної соціальної адаптації індивіда, як мікросвіт, в якому починається особистісне становлення людини. Сім'я є школою людяності, взаєморозуміння, душевного співчуття і співпереживання. Разом з тим, у такій системі інтенсивної тісної взаємодії не можуть не виникати суперечки, конфлікти і кризи. Протиріччя між особистістю та сім'єю неминучі.

Чисельність сімейних конфліктів стрімко зростає, оскільки всі процеси, що відбуваються в суспільстві, відображаються через індивідів на їхніх сім'ях. Як наслідок, сімейні конфлікти стали надзвичайно поширеним явищем, що призвело до стрімкого зростання дисгармонії в сімейних стосунках та чисельності розлучень. У зв'язку з цим проблема вивчення 
взаємодії подружжя у конфліктних ситуаціях, шляхів попередження та вирішення конфлікту набуває особливого значення.

Молода сім'я - це особливий світ, який своєрідно пов'язаний 3 різними проблемами, що стосуються подружньої пари. Зміцнення шлюбу та гармонізація подружніх стосунків, особливо в молодій родині, є одним iз провідних напрямків у практичній психології. Для того, щоб ефективно здійснювати допомогу молодому подружжю, ми повинні мати чітке уявлення про особливості міжособистісних, а особливо подружніх стосунків у родині, а також володіти практичними навиками розв'язання подружніх конфліктів.

Аналіз останніх досліджень $\boldsymbol{i}$ публікацій. Дослідження проблематики конфліктів має тривалу історію. Ще античні мислителі Платон, Арістотель, Епікур вивчали взаємини людей, їхню поведінку в процесі взаємодії, природу виникнення конфліктів на основі раціонального осмислення природи суспільного устрою.

До розгляду різних форм конфлікту зверталися представники практично всіх наукових шкіл і течій західної психології (А. Адлер, Д. Доллар, Д. Креч, Г. Лебон, .. Левін, .. Лоренц, .. Мак-Дугалл, Н. Міллер, С. Сігель, 3. Фрейд, К. Хорні та ін.). Проблеми в уже сформованих сім'ях і спроби їх вирішення досліджували Ю. Альошина, А. Бодальов, І. Борисов, В. Дружинін, О. Зуськова, В. Левкович та інші.

Вивчення вищезазначеної проблематики не залишилося поза увагою й у представників української психологічної науки. Так, умови подолання конфліктів у молодій сім’ї вивчалися Л. Омельченко, психологічні особливості сімейних стосунків сексуально дезадаптованих пар - I. Левановою, вплив рівня домагань подружжя на сімейні стосунки О. Язвінською, особливості протікання сімейної кризи в молодих сім'ях Р. Федоренко.

Таким чином, аналіз науково-психологічної літератури 3 досліджуваної проблеми засвідчив, що причини виникнення, розвитку та вибору подружжям стратегій успішного розв'язання міжособистісних конфліктів у сім'ї, незважаючи на їхню актуальність і важливе практичне значення, поки що вивчені недостатньо. Дотепер залишається не цілком 3'ясовано, чому в одних ситуаціях подружніх конфліктів його сторони воліють використовувати одні стратегії їх розв'язання, в інших - інші; чому одна і та сама стратегія розв'язання конфлікту в одній подружній парі приводить до зміцнення шлюбу, а в іншій - до його розпаду.

Формулювання цілей сmammi: дослідження особливостей подружніх конфліктів і вплив корекційної програми на ефективність їх розв'язання та гармонізацію взаємостосунків у сім'і.

Виклад основного матеріалу. Дослідження, проведені М. Абалкіною, О. Кочетовим, І. Поляковою, Л. Савіновим, В. Сисенко, У. Харлі, засвідчують, що шлюб укладається для взаємного задоволення потреб один одного. Часткове або повне їх незадоволення провокує появу в 


\section{Psychology}

шлюбних партнерів почуття психічного дискомфорту, наслідком якого стають різноманітні конфлікти.

Загалом, конфлікт - це порушення міжособистісних стосунків на рівні поведінки та інтелекту. Зіткнення протилежних інтересів і поглядів, напруження i крайнє загострення суперечностей, що призводить до активних дій, ускладнень, боротьби, що супроводжується складними колізіями. Найбільш сприятливим періодом виникнення конфліктів $\epsilon$ молода сім'я, тобто сім'я зі стажем шлюбного життя не більше 5 років. Щонайменше три зони конфліктів присутні на даній стадії життя родини: функціонально-рольова, потребово-мотиваційна та зона домаганьочікувань.

Сімейні конфлікти відрізняються своїми причинами. Найважливішими 3 них, на думку Л. Шнейдера є: обмеження свободи активності, самовираження членів сім'ї, ненормативна поведінка одного або декількох членів сім'ї, наявність протилежних інтересів, прагнень, обмеженість можливостей для задоволення потреби одного з членів сім'ї (з його точки зору); авторитарний, жорсткий тип взаємостосунків, що склалися в сім'ї, наявність матеріальних проблем, авторитарне втручання родичів у подружні стосунки, сексуальна дисгармонія партнерів у шлюбі тощо [Шнейдер, 2000].

Істотне значення у виникненні конфлікту мають ті очікування, які сформувалися у партнерів до моменту вступу в шлюб під впливом їхніх особистісних особливостей і схильностей та специфіки соціокультурного середовища. Для молодого подружжя найбільш типовими $є$ завищені очікування один до одного, що нерідко $\epsilon$ основою конфлікту в разі розбіжності цих очікувань 3 дійсністю. До основних причин подружніх конфліктів відносять настанову на шлюб як на щось легке і просте. Це може виявлятися також у гедоністичному ставленні до шлюбу, відсутності підготовки до виконання сімейних функцій. Такі тенденції в більшості випадків вказують на недостатню морально-психологічну підготовленість молоді до шлюбу.

Метою нашого емпіричного дослідження було вивчення узгодженості сімейних цінностей (надалі УСЦ) до та після впровадження корекційних впливів. У ньому взяло участь 15 подружніх пар, які перебувають у шлюбі терміном до п'яти років. Віковий розподіл досліджуваних - від 23 до 32 років. УСЦ досліджувалося за допомогою методики «Рольові очікування і домагання у шлюбі» (РОД) А. Волкової.

Нами була створена корекційна програма «Розв'язання подружніх конфліктів та гармонізація сімейних стосунків», яка мала на меті гармонізацію подружніх стосунків, а саме: навчання партнерів розв'язанню конфліктних ситуацій, формування навичок конструктивного спілкування в подружжі тощо. 
Завданням корекиійної програми було:

- ознайомити подружні пари 3 конструктивними способами розв’язання конфліктів у сім'і; спілкуванні;

- підвести до усвідомлення необхідності шанобливих стосунків у

- навчити цінувати своїх близьких і допомагати одне одному;

- сприяти формуванню позитивної «Я-концепції»;

- розвивати форми і навички особистісного спілкування, способи взаєморозуміння.

Після впровадження корекційної програми 3 досліджуваними парами був проведений контрольний експеримент, результати якого представлено на рис. 1.

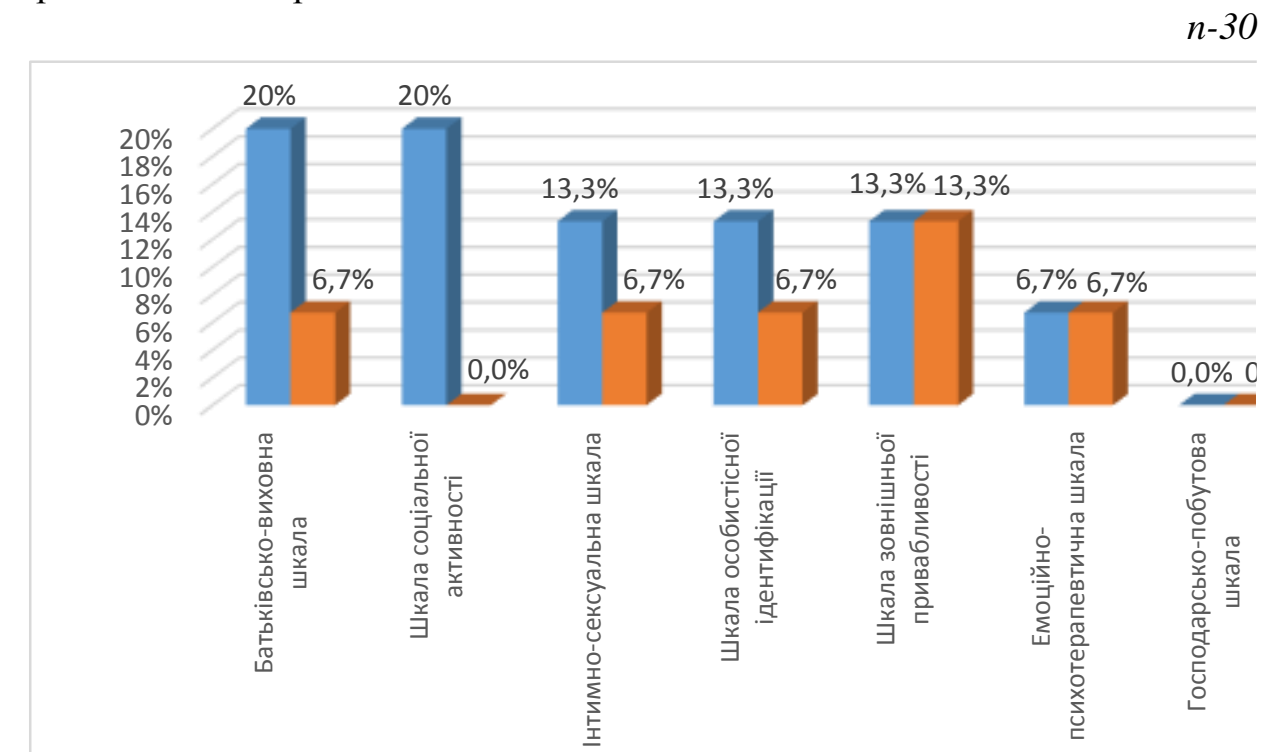

Рис. 1. Узгодженість сімейних цінностей досліджуваних до та після корекційної програми (у \%).

Як свідчать дані, подані на рис. 1, результати контрольного експерименту значно покращилися порівняно з констатувальним.

Виявлено суттєву різницю між відсотковими показниками за батьківсько-виховною шкалою, яка діагностує задоволення індивідуальних потреб у батьківстві та материнстві, самореалізації особистості в дітях. Показники конфліктності зменшилися на 13,3% (від 20 \% до 6,7 \%). Тобто, після впровадження корекційних впливів лише у 6,7 \% пар спостерігалося загострення проблемних взаємин щодо ставлення чоловіка (дружини) до своїх батьківських обов'язків. Про це свідчить той факт, що після здійснення корекційних впливів, один 3 партнерів так і не змінив свого ставлення до виконання виховних функцій у сім’і, тобто як і раніше не 


\section{Psychology}

вважає батьківство основною цінністю життя родини. У свою чергу, таке ставлення до дітей не влаштовує іншого партнера, що провокує загострення конфлікту.

За шкалою соціальної активності результати досліджуваних покращилися на $20 \%$ (від $20 \%$ до $0 \%$ ). Оскільки формування активної громадянської позиції успішно здійснюється в процесі партнерської взаємодії індивіда 3 соціальним середовищем, важливою умовою цього процесу стала організація одним 3 партнерів діяльності таким чином, щоб iï суб'єктом був інший партнер і щоб ця діяльність мала добровільний та особистісно-мотиваційний характер участі в ній. Порівнюючи результати констатувального та контрольного етапів дослідження, спостерігається позитивний вплив корекційної програми на взаємини у подружніх парах. Адже, до формувального експерименту більший відсоток партнерів були не задоволені способом існування і розвитку особистості іншого партнера як суб'єкта суспільного життя.

За інтимно-сексуальною шкалою після впровадження корекційної програми результати покращилися на 6,6\% (від 13,3\% до 6,7\%). Залишилися $6,7 \%$ пар, в яких один 3 партнерів не задоволений подружньою взаємодією. Цей відсоток можна інтерпретувати як недооцінку сексуальних стосунків у шлюбі. Можливою є й така думка у одного 3 партнерів, що сексуальна гармонія не $є$ важливою умовою подружнього щастя.

Утім 6,6\% подружніх пар після участі в тренінгу усвідомили, що важливим і невід`ємним для партнерів є зближення та інтимна сторона стосунків, а останні, у свою чергу, сприяють задоволенню функціональних потреб особистості в спілкуванні, самореалізації і т. п.; нормальні сексуальні взаємини $є$ найважливішим чинником, який визначає успішність сімейного життя. Духовний світ партнерів не можна відірвати від статевої площини взаємин у сім'ї. Втім, спільність інтересів, світогляду, взаємна любов і повага, психологічне співзвуччя, у свою чергу, не менше важливі в шлюбі, ніж статеве життя.

На думку таких дослідників сім'ї, як В. Сисенко, Ю. Рюрікова, А. Харчева, розпад багатьох шлюбів обумовлений психологічною та сексуальною неосвіченістю партнерів, яка заважає знайти оптимальний контакт, уникнути конфлікту, адаптуватися до партнера. Характер сексуальних взаємин залежить від гармонії, сумісності сексуальних настанов, поглядів партнерів, сексуальної обізнаності та рівнів їхньої сексуальної культури, відповідності темпераментів тощо.

3. Фрейд показав роль і значення сексуальності в житті людини. У світлі його теорії стає зрозумілою необхідність сексу не лише для продовження роду і періодичного розвантаження, але й для задоволення всіх функціональних потреб особистості (в спілкуванні, самореалізації і ін.). Це означає, що сексуальність не можна розглядати поза особистістю, а особистість без урахування іiї сексуальних переживань. 
Наступна икала особистісної ідентифікаиії відображає настанову дружини (чоловіка) на особистісну ідентифікацію 3 партнером. Ідентифікація виступає в якості одного 3 механізмів пізнання та розуміння іншої людини. За цією шкалою результати покращилися на 6,6\% (від 13,3 \% до 6,7 \%) після впровадження корекційної програми. Тобто, певний відсоток досліджуваних змогли покращити взаємини та уникнути неузгодженості завдяки намаганням одного з подружжя зрозуміти іншого через усвідомлене чи неусвідомлене ототожнення його з собою; партнери намагалися розуміти стан і настрій іншого, сприймати ставлення партнера до світу й до себе, поставивши себе на місце іншого.

За шкалою зовнішньої привабливості високу ймовірність конфліктних ситуацій можна спостерігати у 13,3\% подружніх пар. Відсоткові результати після апробації корекційної програми залишилися незмінними. Чоловік (дружина), як i раніше, бажали мати зовнішньо привабливого партнера, оскільки для них дуже важливо, щоб партнер сучасно та красиво одягався і завжди слідкував за собою. Неохайне та байдуже ставлення одного 3 партнерів до свого зовнішнього вигляду, байдужість до точки зору оточуючих (партнера) щодо вибору одягу, стилю зачіски тощо часто провокують конфліктну ситуацію в таких сім'ях. Таке вимогливе ставлення до зовнішності партнера, у свою чергу, може бути витлумачене 3 точки зору плинності моди, нав'язаних рекламою соціальних маркерів краси.

Результати за емоиійно-психотерапевтичною шкалою після впровадження корекційних впливів також залишилися незмінними. Успішна реалізація цієї функції означає задоволення потреб партнера у визнанні, любові, турботі, психологічному захисті. Зовнішнім і об'єктивним показником такої сумісності є сам факт збереження сім'ї. Внутрішнім і суб'єктивним показником цього почуття у членів родини $є$ наявність психологічного комфорту, надійності, задоволення від спілкування одного з одним. Утім 6,7\% досліджуваних, як і раніше, демонструють високу конфліктність у взаємодії. Це свідчить про те, що один з партнерів у цих сім'ях нехтує моральною та емоційною підтримкою іншого, не прагне створити «психотерапевтичну атмосферу» в родині.

Господарсько-побутова шкала, що вимірює настанову жінки й чоловіка на реалізацію господарсько-побутової функції сім’і, спрямована на задоволення матеріальних потреб членів сім’ї, забезпечення умов для збереження i зміцнення їхнього здоров'я, організацію відпочинку. Переважна більшість досліджуваних продемонструвала вміння конструктивно розв'язувати побутові проблеми, активно беручи участь у домашньому господарстві, розуміють значущість побутової організації сім'ї, розподіляють обов'язки та цінують старання один одного.

Таким чином, можна констатувати, що впровадження корекційних впливів позитивно вплинуло на превенцію та розв'язання подружніх конфліктів у сферах виконання батьківсько-виховних функцій, соціальної 


\section{Psychology}

активності, особистісної ідентифікації та інтимно-сексуальних стосунків.

Висновки. Актуальність дослідження полягала у вивченні взаємодії подружжя в конфліктних ситуаціях, розробці психокорекційних впливів 3 метою їх запобігання та усунення й оцінці ефективності корекційної програми. Для цього була використана адекватна предмету дослідження методика «Рольові очікування і домагання у шлюбі» (РОД) А. Волкової.

Результати контрольного експерименту засвідчили ефективність впровадження корекційних впливів. Так, тренінг сприяв формуванню навичок безконфліктного розв'язання проблемних ситуацій у сім’і, що передбачало покращення комунікативних навичок спілкування партнерів, врахування інтересів та потреб один одного, розвиток доброзичливості та гармонізацію взаємостосунків у родині.

\section{ЛІТЕРАТУРА}

Гришина, 2012 - Гришина Н. В. Психология конфликта. Санкт-Петербург : Питер, 2012. 464 с.

Дуткевич, 2005 - Дуткевич Т. В. Конфліктологія з основами психології управління : навчальний посібник. Київ : Центр навчальної літератури, 2005. 256 с.

Карнеги, 2004 - Карнеги Д. Как завоевать друзей / пер. с англ. З. П. Вольской, Ю. В. Семенова. Донецк : «Издательство Сталкер», 2004. 560 с.

Кочетов, 1989 - Кочетов А. И. Начало семейной жизни. Минск : «Полымя», 1987. 224 с.

Пірен, 2007 -Пірен М. І. Конфліктологія : Підручник. Київ; МАУП, 2007. 360 с.

Райгородский, 2002 - Райгородский Д. Я. Практическая психодиагностика. Методики и тесты : учебное пособие. Самара : «БАХРАХ-М», 2002. 672 с.

Сысенко, 1989 - Сысенко В. А. Супружеские конфликты. Москва : Мысль, 1989. 173 с.

Харченко, 2007 - Харченко С. В. Особенности общения мужчин и женщин. Практична психологія та соиіальна робота. 2007. № 4. С. 12-16.

Шнейдер, 2000 - Шнейдер Л. Б. Психология семейных отношений. Курс лекций. Москва : Апрель-Пресс, Изд-во ЭКСМО-Пресс, 2000. 512 с.

\section{REFERENCES}

Hryshyna, 2012 - Hryshyna N. V. Psykholohyia konflykta. SPb. : Pyter, 2012. 464 s.

Dutkevych, 2005 - Dutkevych T. V. Konfliktolohiia z osnovamy psykholohii upravlinnia : navchalnyi posibnyk. Kyiv : Tsentr navchalnoi literatury, 2005. $256 \mathrm{~s}$.

Karnehy, 2004 - Karnehy D. Kak zavoevat druzei / per. s anhl. Z. P. Volskoi, Yu. V. Semenova. Donetsk : «Yzdatelstvo Stalker», 2004. $560 \mathrm{~s}$.

Kochetov, 1989 - Kochetov A. Y. Nachalo semeinoi zhyzny. Mynsk : «Poldmia», 1987. 224 s.

Piren, 2007 - Piren M. I. Konfliktolohiia : Pidruchnyk. Kyiv; MAUP, 2007. 360 s.

Raihorodskyi, 2002 - Raihorodskyi D. Ya. Praktycheskaia psykhodyahnostyka. Metodyky y testы : uchebnoe posobye. Samara : «BAKhRAKh-M», 2002. $672 \mathrm{~s}$.

Sysenko, 1989 - Sysenko V. A. Supruzheskye konflykty. Moskva : Mysl, 1989. 173 s.

Kharchenko, 2007 - Kharchenko S. V. Osobennosty obshchenyia muzhchyn y zhenshchyn. Praktychna psykholohiia ta sotsialna robota. 2007. № 4. S. 12-16.

Shneider, 2000 - Shneider L. B. Psykholohyia semeinykh otnoshenyi. Kurs lektsyi. Moskva : AprelPress, Yzd-vo EKSMO-Press, 2000. 512 s. 